Halimeh Enayat, Mahdokht Anbary Roozbahany"

Faculty of Social Sciences, Shiraz University, Shiraz, Iran

\section{The Study of Pshycho-Social Factors Related to Women Tendecy to Cosmetic Surgeries (A Case Study: The Women Population Aged 15-50 of Shiraz)}

Received:15 Jul. 2017; Accepted:4 Jan. 2018

Introduction: Plastic surgery intended to beautify has emerged along with modernity. It becomes one of the social norms by majority acceptance and it is considered as one of the individual daily concerns, particularly among women. In this research, it is stressed on the necessity of studying the psychological reasons women; tend to cosmetic surgery.

Materials and Methods: This study is a survey and the data collection tool are standard Rosenberg self-esteem questionnaire (SES) and self-image questions based on Schilder theory that are filled by 400 people of women living in Shiraz in 1394. Then collected data was analyzed through SPSS16 software by logistic regression, chi-squared test and phi Cramer. The sampling was geographical cluster multistage. With the help of the urban block map, areas were randomly selected and questionnaires were given to the respondents at their homes.

Results: It is found that there is a meaningful relationship between the studied depended variable and income, age and education. A significant relationship between marital status and the rate of cosmetic surgery has been also confirmed.

The existing meaningful relationship between married status and the rate of trend toward cosmetic surgery is denied. The significant relationship between employment and trend rates toward cosmetic surgery is rejected. By increasing the rate of self-esteem and satisfaction of physical image, trend to cosmetic surgery decreases

Conclusion: Modernity has provided a different conditions from before for everyone. It has given the power of choice and power of change to people including changes in body. In this research, which aims to study psychological factors affecting women tendency to cosmetic surgery, the findings are consistent with theoretical social psychology written in this study. But with the recent changes, some thinkers Considered, being a woman is highrisk in this period and they believe that the female body which is approved by others will be defined in a risky culture.

Keywords: Cosmetic Surgery, Social Psychology, Body, Self, Self-esteem, Body-image

*Corresponding Author: Faculty of Social Sciences, Shiraz University, Shiraz, Iran

Tel: 0912- 2823558 E-mail: mahdokht56@gmail.com 


\section{بررسى علل روانى تَرايش زنان به جراحىهاى زيبايى (مطالعه موردى: زنان +ه-ها (هال سال شهر شيراز)}

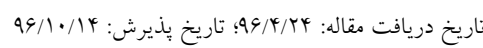

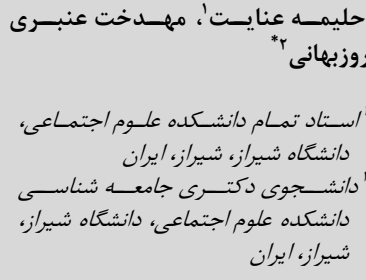
شيراز، ايران

حكيده

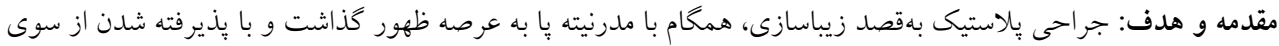

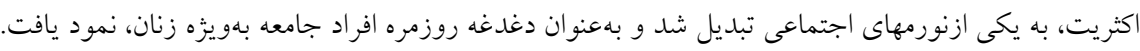

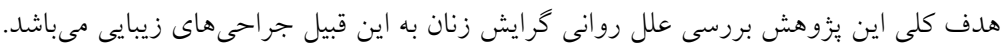

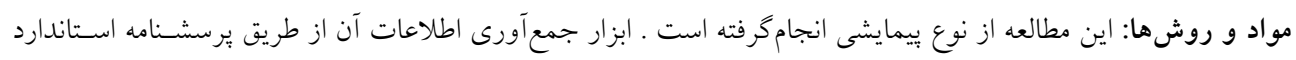

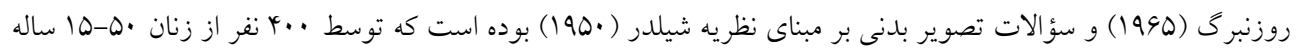

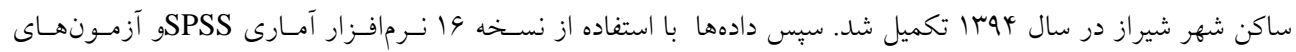

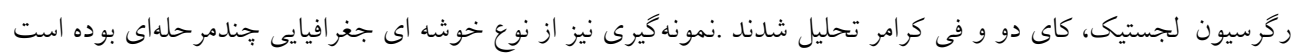

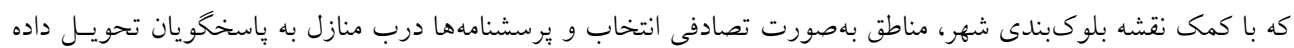

يافته هاى بزٔوهش: مشخص گرديد كه متغير وابسته موردمطالعه، يعنى ميزان كرايش و ميزان اقدام به جراحىهاى زيبايى،بـا

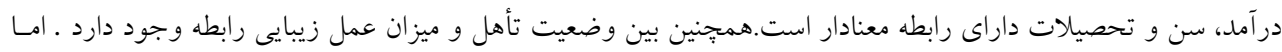

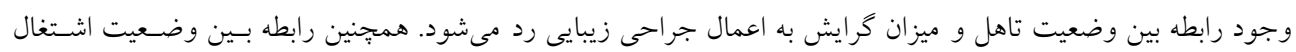

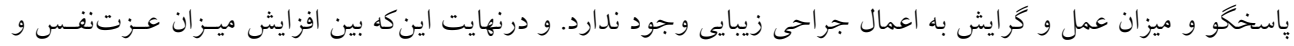

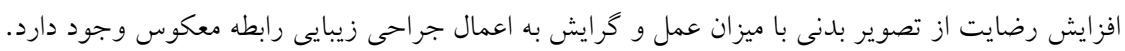

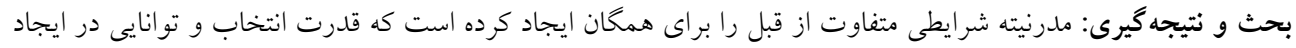

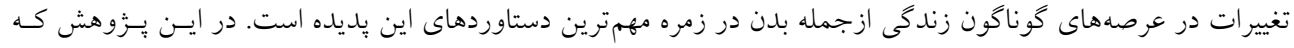

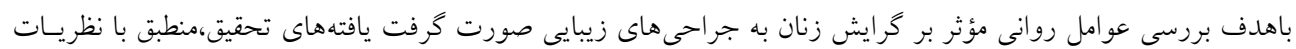

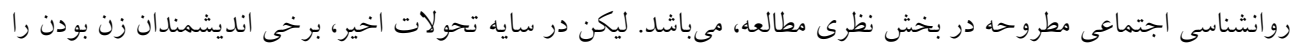

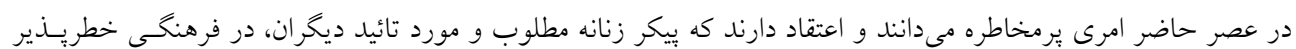

$$
\text { تعريف مىشود. }
$$

كلمات كليدى: جراحى زيبايى، روانشناسى اجتماعى، بدن، خود، عزتنفس، تصوير بدنى
"نويسنده مسئول:

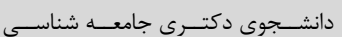

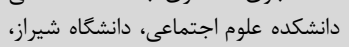

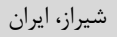

QIT-KATKOAN

E-mail: mahdokht56@gmail.com 
خاصى يافته و ور مطالعات اخير بلهعنوان عاملى توانمنــــ و اثركـــار مقدمه

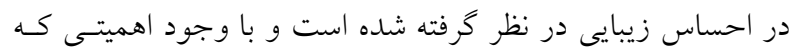
"خود" در يزووهش ها كسب كرده، به نحوى، مبدل به مبنـايى بـراى سنجش امور رفتارى و روانى در افراد مىباشد.'

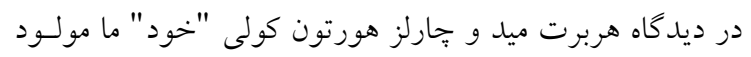

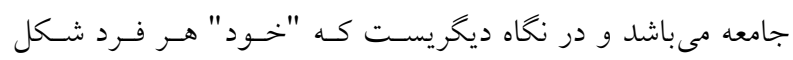

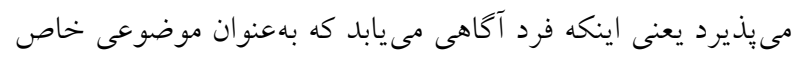

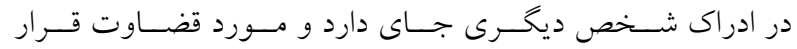

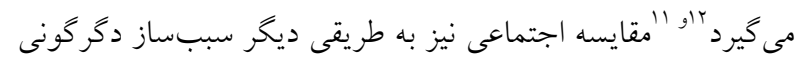

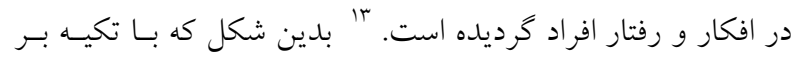

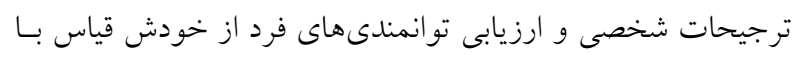

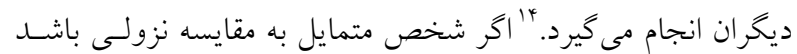

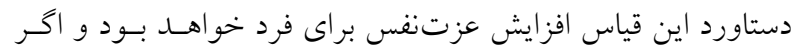
مقايسه صعودى باشد حس محروميـت در فـرد شكل مسى كيـرد. 10

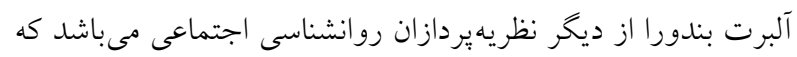

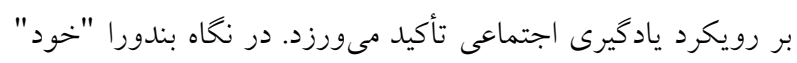

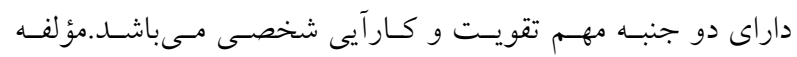
عزتنفس و خودباورى در، كارآيى شخصى، يديدار مىشود. افرادى كه داراى عزتنفس بالا هستند به توانمندى هاى خود ايمان داشته و داراى عملكرد موفق ترى در جامعسه نسـبت بـه سـايرين هسـتند. 19 درنهايت اين كه در نظريه بندورا خود داراى اهميـت بسيسار زيـادى لرى

مطالعات انجامشده در داخل و خارج كشـور حـاكى از اهميـت اين مسئله بهعنوان بِديده اي اجتمـاعى و روانسى در سـطح جهانى

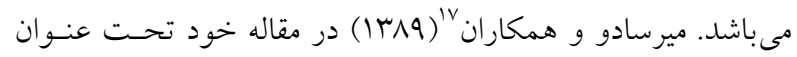

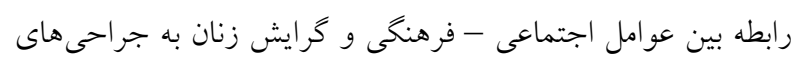
زيبايى در شهر كرج، دريافتند كه متغيرهاى در آمد، مقايسـه و تقليـد از دوستان از مهمترين عوامل كرايش به جراحىهـاى زيبـايى بـودهـ

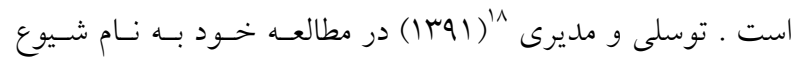
جراحى زيبايى در بين زنان تهرانى بــ ايسن نتيجـه رسـيدهانــ كـه

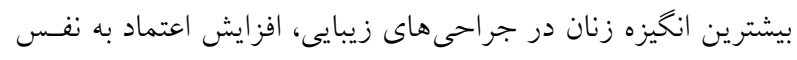
بوده و عواملى جون تجـرد، تحصسيلات بـالا، داشستن نارضـايتى از

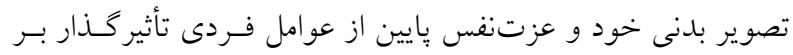

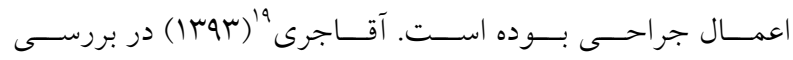

در عصر مدرن، توانـايى ايجـاد تغييـرات و قــدرت انتخـاب در

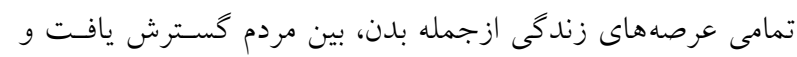

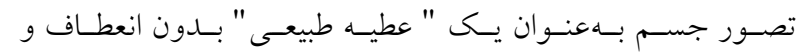
تغييرنايذير كمرنخ شد' و بدن بهعنوان يك "ِـروزه ناتمـام" و نيـز

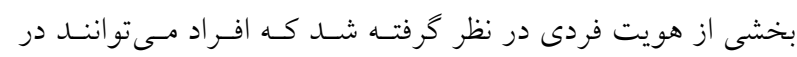

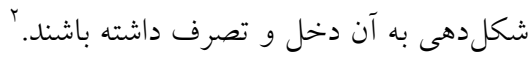

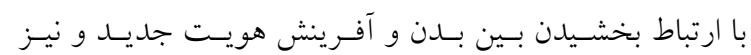

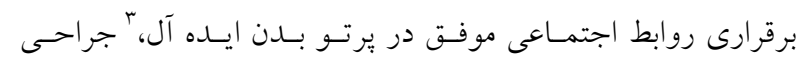

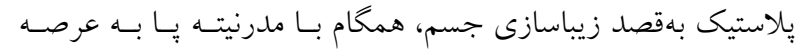

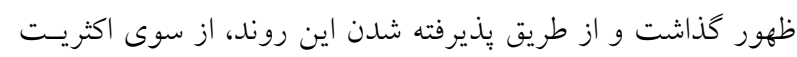

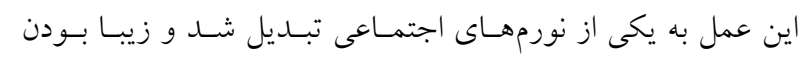

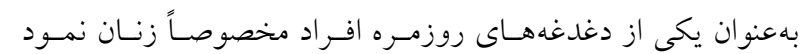

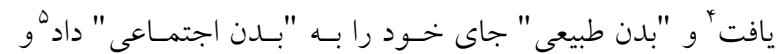
اين جنين شد كه ظاهر انسان مبدل به محصولى، ساخته دست بشرى

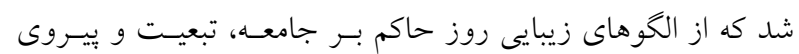
مى كرد. ايران نيز همانند ساير كثـورها، بـا حركت بـهـ سـمت وسـوى

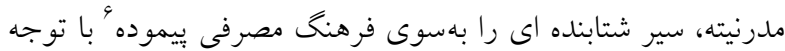

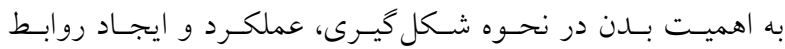

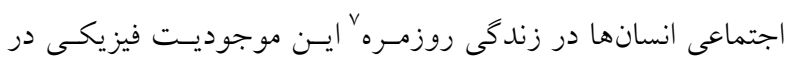

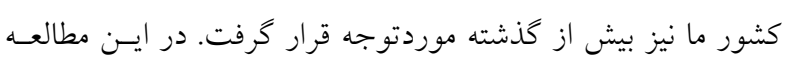

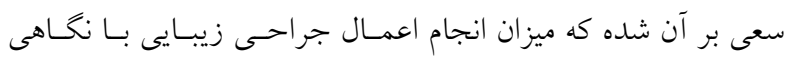

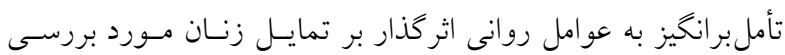
قرار خيرد.

در رهيافت روانشناسى اجتماعى با تأكيد بر ارتباط بـين تصـوير

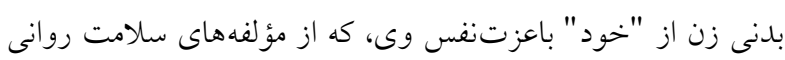

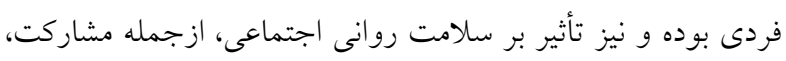
خودشكوفايى و انسجام اجتماعى همجنين با لحساظ كـردن تـأثير و

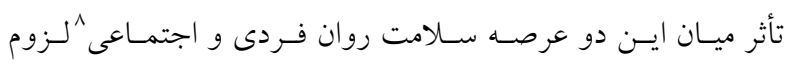

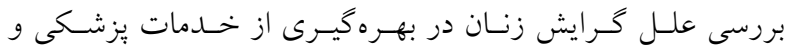
جراحىهاى زيبايى بدون علت، مورد تائيد و تأكيد قرار مى گيرد .

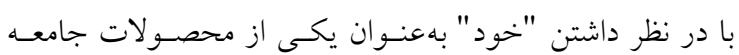
مدرن،"بدن" نيز بهعنوان واضحترين و آشكارترين حامل آن جايخاه 


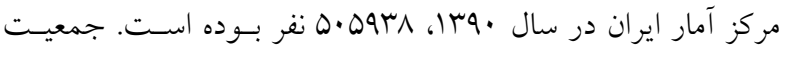

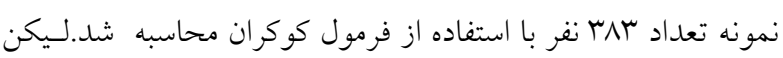

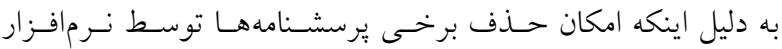

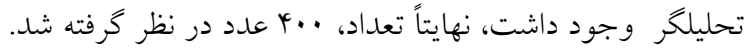
$n=\frac{\frac{z^{2} p q}{d^{2}}}{1+\frac{1}{N}\left(\frac{z^{2} p q}{d^{2}}-1\right)}$ فرمول كوكران نمونه كيرى نيز از نوع خوشه اى جغرافيايى جندمرحلهاى بـوده است. در ابتدا شهر به جهار منطقه جغرافيايى شمال، جنوب، شرق و و غرب تقسيم شد و با استفاده از روش نمونه گيرى تصادفى از شـمال

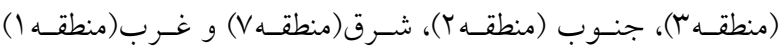
انتخاب شدند. در ادامه نمونه گيرى، با كمك نقشه بلوكبنـدى شـهر

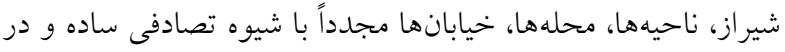

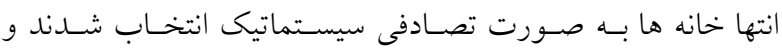
يرسشنامهها توسط برسشخران در درب منازل در اختيار بِاسخحويان قرار كرفت. دادههاى كردآورىشــده، نيـز بــا اسـتفاده از نسـخه 19 نرمافـزار آمـارى اس يسى اس اس تجزيـهـ و تحليـل شـــ و بِيــايى يرسشنامه نيز از طريق آلفاى كرونباخ محاسبه شد. اعتبار يرسشـنامه نيز از نوع صورى بوده كه توسط متخصصين تائيد كرديد.

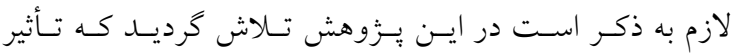

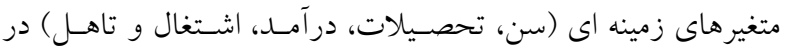

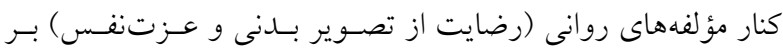

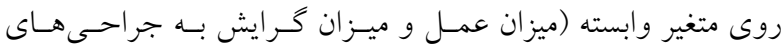
زيبايى) در زيرسشنامه موردسـنش قـرار كيـرد. همجنسين جراحسى

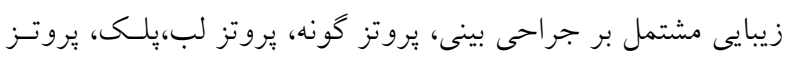

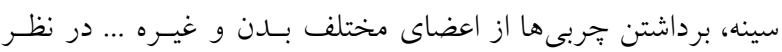
كُرفته شد و بهطوركلى هر جراحى كه به قصـد زيباسـازى در اتـاق

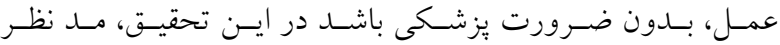
قرارگرفت .همانطور كه مطرح شـــ متغيـر وابسـته نيـز در دو بعـــ

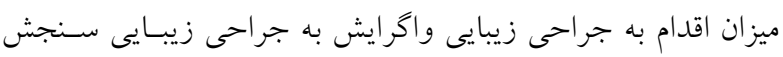

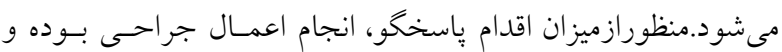

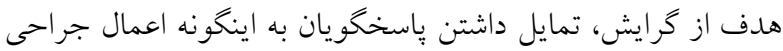
مىباشد و جنبه اى ذهنى را دربرمى گيـــد.بـهـنظـور سـنجش متغيـر وابسته اين مطالعه در هر دو بعد عملسى و ذهنى،فهرسـت مطروحسه

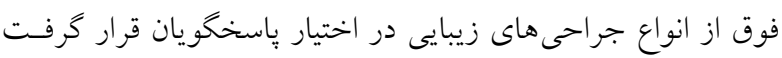

جامعهشناختى آرايش و جراحىهـاى زيبـايى در تهـران، متغيرهـاى محل سكونت، درآمد و سطح تحصيلات فرد را از عو امل تأثيركـذار بر گرايش به اعمال جراحى زيبايى دانسته و بين همسالان و گرايش به جراحىهاى زيبايى رابطه معنى دارى نيافته است.ساختار عـاملى و روانسنجى نسخه ايتاليايى از يذّيرش برسشنامه جراحسى زيبـايى، از

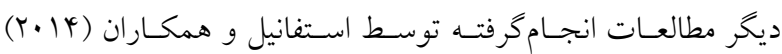

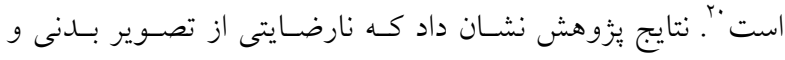
ساختارهاى فرهنكى و اجتماعى حساكم بـر جامعسه داراى بـالاترين

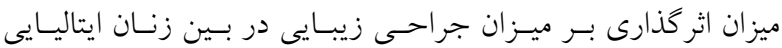
مىباشد. سوئست و همكاران (9.9) در مطالعه خود، دريافتند كه بين برونكرايى، ارزيابى فرد از تصوير بلدنى خود و تمايل به جراحى هولى

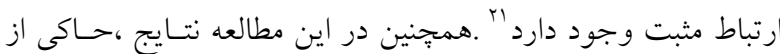
رابطه معكوس عزت نفس با ميزان تقاضـا در جراحسى زيبـيى بـود.

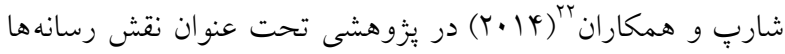
و تأثيرات همالان بر نخرش زنان استراليايى نسبت به جراحى زيبايى دريافتند كه انجام اعمال جراحى در بين مجـردان بـيش از متـأهلين مىباشد. همجنين در بين ساير متغيرهـاى مسـتقل همجهـون تصـوير منفى بلدنى، فشارهاى هنجارى، تبليغات، همسالان و مقايسه بــنى،

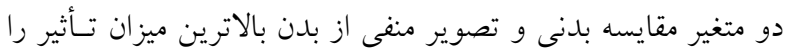
بر روى گرايش و انجام به جراحى زيبايى دارا هستند.

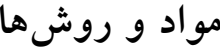

اين مطالعه از نوع بيمايشى انجام گرفته است ـ ابزار جمـع آورى طالاعات از طريق برسشـنامه اسـتاندارد روزنبـرى كويه در سطح فاصله اى- نسبى با ضـريب آلفـاى كرونبـاخ و1/•و

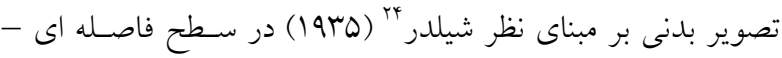

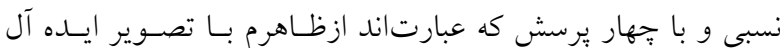
ذهنى كه داشتم متفاوت بود، از ظاهر خود احساس رضـايت كامـل دارم، خود را زيبا مى يندارم و اندام خود را كاملاً متناسب مسى بيـنم

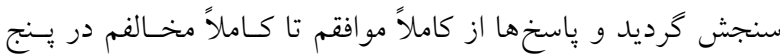

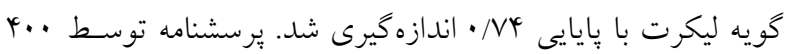

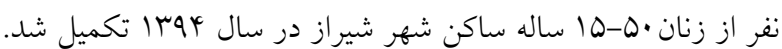

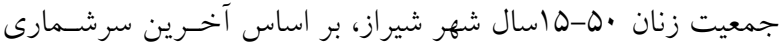


مشاهده مى شود.

با در نظر داشتن فراوانى عمل هاى انجامشده يا فراوانى تمايل به عمل هاى موردعلاقه افراد، مشخص كرديد كه نيمى از جامعه نمونه،

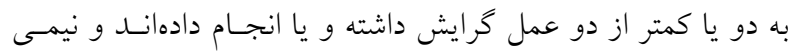

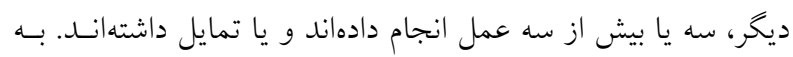

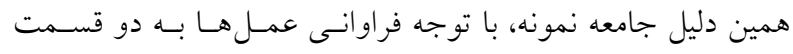
تقسيمبندى شد.
و از آنان خواسته شد تا ميزان اقدام به عمل و يــا تمايسل بـه انجـام

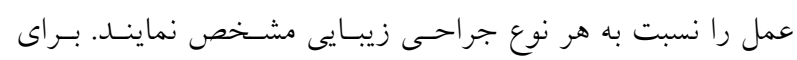

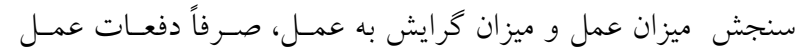
فارغ از نوع جراحى مدنظر مىباشد.

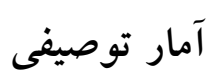

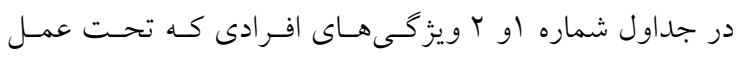
جراحى قرارگرفتهاند و كسانى كه به عمـل جراحسى گـــايش دارنـــ

جدول ا: ويزگى افرادى كه تحت عمل جراحى زيبايى قرارگرفتهاند

\begin{tabular}{|c|c|c|c|c|c|c|c|c|c|c|c|c|c|c|}
\hline \multicolumn{3}{|c|}{ اشتغال } & \multicolumn{3}{|c|}{ تا هل } & \multicolumn{3}{|c|}{ درآمد } & \multicolumn{3}{|c|}{ تحصيلات } & \multicolumn{3}{|c|}{ سن } \\
\hline$q r$ & فراوانى & شاغل & 94 & فراوانى & مجرد & rr & فراوانى & كمتر از V. ك & r & فراوانى & ابتدايى & VY & فراوانى & $10-Y^{K}$ \\
\hline $9 \mathrm{~V}$ & فراوانى & خانهدار & rq & فراوانى & متأهل & 0 & فراوانى & $v_{\cdots-1 / r \cdots}$ & $r y$ & فراوانى & سيكل & rr & فراوانى & $r Q-r Y$ \\
\hline \multirow[t]{7}{*}{19.} & فراوانى & جمع & rI & فراوانى & مطلقه & rq & فراوانى & $1 / r \cdots-1 / N \cdots$ & ry & فراوانى & دييلم & $r_{4}$ & فراوانى & $r Q-k \psi$ \\
\hline & & & 1. & فراوانى & همسر & 4. & فراوانى & $1 / V \cdots-r / r \cdot \cdot$ & 11 & فراوانى & فوقدييلم & rI & فراوانى & هtwlJ \\
\hline & & & & & فوتشده & & & & & & & & & و بالاتر \\
\hline & & & 191 & فراوانى & جمع & IV & فراوانى & بيشتر از “.. & $9 \Lambda$ & فراوانى & ليسانس & 191 & فراوانى & جمع \\
\hline & & & & & & $|r|$ & فراوانى & جمع & 11 & فراوانى & فوقليسانس & & & \\
\hline & & & & & & & & & $r$ & فراوانى & دكترى & & & \\
\hline & & & & & & & & & 19. & فراوانى & جمع & & & \\
\hline
\end{tabular}

جدول r: ويزَى افرادى كه تمايل به انجام عمل جراحى زيبايى دارند

\begin{tabular}{|c|c|c|c|c|c|c|c|c|c|c|c|c|c|c|c|}
\hline & & اشتغال & & & & تا هل & & & در آمد & & & تحصيلات & & & سن \\
\hline $1 r q$ & فراوانى & شاغل & $11 \%$ & فراوانى & & مجرد & ro & فراوانى & كمتر از V.. & V & فراوانى & ابتدايى & Vo & فراوانى & $1 Q-K^{4}$ \\
\hline$\wedge \cdot$ & فراوانى & خانهدار & Qr & فراوانى & & متأهل & v & فراوانى & $v \cdots-1 / r \cdots$ & 0. & فراوانى & سيكل & v. & فراوانى & $r Q-M E$ \\
\hline \multirow[t]{6}{*}{ r19 } & فراوانى & جمع & 4 & فراوانى & & مطلقه & rr & فراوانى & $1 / T \cdots-1 / v \cdots$ & r. & فراوانى & دييلم & \&V & فراوانى & $r \Delta-\mu \varphi$ \\
\hline & & & 19 & فراوانى & رلروتشده & همسر & $\Delta r$ & فراوانى & $1 / V \cdots-r / r \cdots$ & $1 \pi$ & فراوانى & فوقدييم & ri & فراوانى & و هالاتـال \\
\hline & & & YYI & فراوانى & & جمع & rr & فراوانى & بيشتر از ·r. & $\wedge 1$ & فراوانى & ليسانس & rTr & فراوانى & جمع \\
\hline & & & & & & & 179 & فراوانى & جمع & rq & فراوانى & فوقليسانس & & & \\
\hline & & & & & & & & & & 0 & فراوانى & دكترى & & & \\
\hline & & & & & & & & & & rrT & فراوانى & جمع & & & \\
\hline
\end{tabular}




\begin{tabular}{|c|c|c|}
\hline درصد & فراوانى & ميزان عمل زيبايى \\
\hline$\Delta r$ & VQ & كمتر يا مساوى با Y عمل \\
\hline 49 & 19 & بيش از Y عمل \\
\hline $1 \ldots$ & 191 & جمع كل \\
\hline
\end{tabular}

\begin{tabular}{|c|c|c|}
\hline درصد & فراوانى & ميزان عمل زيبايى \\
\hline$\psi \wedge$ & 114 & كمتر يا مساوى با r عمل \\
\hline or & irr & بيش از r عمل \\
\hline $1 .$. & rmo & جمع كل \\
\hline
\end{tabular}

متغير زمينه اى سن، درآمد و تحصيلات با ميزان عمل و ميزان تمايل

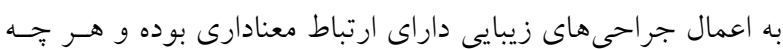
سن، سطح درآمد و تحصيلات فرد بالاتر مىرود هـم ميـزان انجـام آنساط

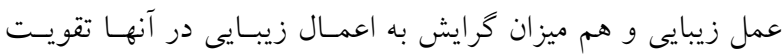

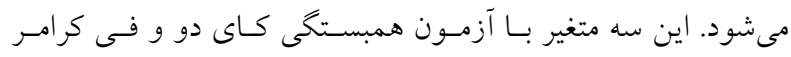
سنتش شل
با توجه به اين كه متغير وابسته يزوهش از نوع كيفـى مس باشـــ

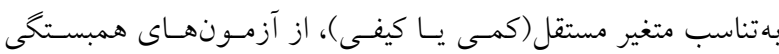
ركرسيون لجستيك، كاى دو و فى كرامر استفاده مى مشود.

\section{يافته هاى يخووهش}

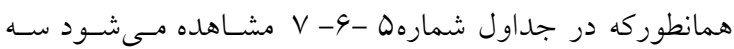

\begin{tabular}{|c|c|c|c|c|}
\hline نتيجه فرضيه & سطح معنى دارى & مقدار & & متغير \\
\hline \multirow[t]{2}{*}{ تائيد } &.$/ \cdot 14$ & $1 \cdot / O V F$ & آماره كاى دو بيرسون & ميز ان عمل \\
\hline &.$/ \cdot 14$ & $\cdot / r \Delta Q$ & آماره فى كرامر & \\
\hline \multirow[t]{2}{*}{ تائيد } & $\%$ & $1 r / 40$. & آماره كاى دو يِيرسون & تمايل به عمل \\
\hline & $1 / .94$ & $\cdot / \pi r 4$ & آماره فى كرامر & \\
\hline
\end{tabular}

جدول و: نتيجه آزمون همبستكى كاى دو و فى كرامر براى بررسى رابطه تحصيلات با ميزان عمل و تمايل به عمل

\begin{tabular}{|c|c|c|c|}
\hline نتيجه فرضيه & سطح معنى دارى & مقدار & \\
\hline \multirow{2}{*}{ تائيد } & $\cdot \ldots$ & TY/Y9O & آماره كاى دو يِيرسون \\
\hline & $\bullet \cdots$ & $\cdot \pi \wedge q$ & آماره فى كرامر \\
\hline \multirow{2}{*}{ تائيد } & $\cdot \cdots$ & $r \mu / N \mu_{\Lambda}$ & آماره كاى دو ييرسون \\
\hline & $\cdot \ldots$ & 年 & آماره فى كرامر \\
\hline
\end{tabular}




\begin{tabular}{|c|c|c|c|c|}
\hline نتيجه فرضيه & سطح معنىدارى & مقدار & & متغير \\
\hline \multirow[t]{2}{*}{ 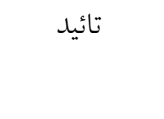 } & $\cdot / \cdot r$. & $11 / 9 T V$ & آماره كاى دو بيرسون & ميزان عمل \\
\hline & $\cdot / \cdot r \cdot$ & $\cdot / r 91$ & آماره فى كرامر & \\
\hline \multirow[t]{2}{*}{ 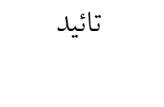 } & $\cdot / \cdot r$ & lQ/VQY & آماره كاى دو يِيرسون & تمايل به عمل \\
\hline & $\cdot / \cdot r$ & $\cdot \pi r V$ & آماره فى كرامر & \\
\hline
\end{tabular}

\begin{tabular}{|c|c|c|c|c|}
\hline نتيجه فرضيه & سطح معنىدارى & مقدار & & متغير \\
\hline \multirow{2}{*}{ رد } & $\cdot / 1 \cdot v$ & $T / 090$ & آماره كاى دو ييرسون & \multirow{2}{*}{ بيزان عمل } \\
\hline & $\cdot / 1 \cdot v$ & $-\cdot / T Y V$ & آماره فى كرامر & \\
\hline \multirow{2}{*}{ נ2 } & $\cdot / v \cdot r$ & $\cdot / 140$ & آماره كاى دو يِيرسون & \multirow{2}{*}{ تمايل به عمل } \\
\hline & $\cdot / v \cdot r$ & / RG & آماره فى كرامر & \\
\hline
\end{tabular}

عمل رابطه معنادارى وجود دارد. و با توجه به آماره كاى دو يبيرسون

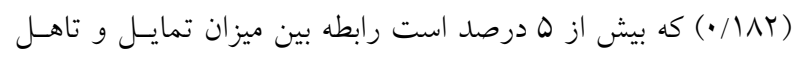
تائيد نشده است. اين متغير تاهل نيز همانطور كه مشاهده مسى شـود

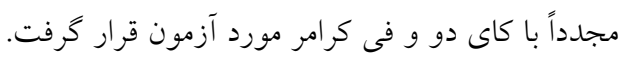

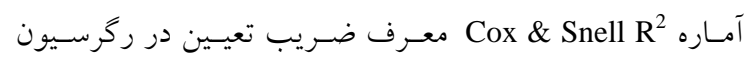
لجستيك مى باشد. ضريب تعيسين ميـزان درصــ تغييراتسى از متغيـر

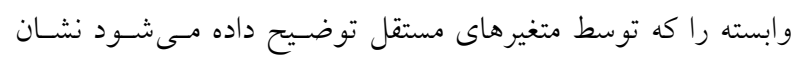
مى دهد.
با توجه به نتايج جدول، مىتوان نتيجه گرفت كه بين اين متغيـر مستقل و متغير وابسته يُزوهش رابطه معنادارى وجود ندارد. متغيـر

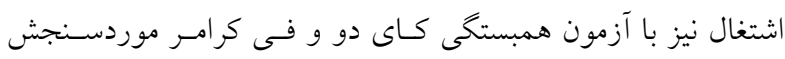

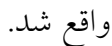
با توجه به خروجى جدول شماره 9- مشاهده مسىشـود سـطح

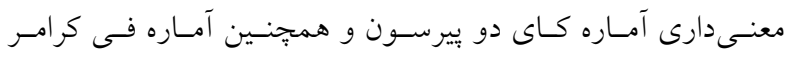

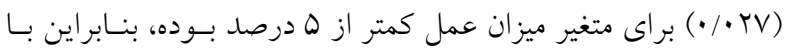

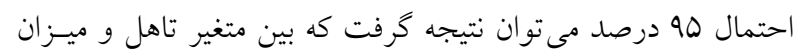

جدول 9: نتيجه آزمون همبستكى كاى دو و فى كرامر براى بررسى رابطه تاهل با ميزان عمل و تمايل به عمل در شهر شيراز

\begin{tabular}{|c|c|c|c|c|}
\hline نتيجه فرضيه & سطح معنىدارى & مقدار & متغير & \\
\hline \multirow[t]{2}{*}{ تائيد } & $\cdot / \cdot T V$ & $9 / 1 \wedge 9$ & آماره كاى دو يِيرسون & ميزان عمل \\
\hline & $\cdot / r V$ & $\cdot / r \mu a$ & آماره فى كرامر & \\
\hline \multirow[t]{2}{*}{ رد } & $\cdot / M A$ & $Y / \Lambda G Y$ & آماره كاى دو يِيرسون & تمايل به عمل \\
\hline & $\cdot / \Lambda \wedge r$ &.$/ 14 \lambda$ & آماره فى كرامر & \\
\hline
\end{tabular}


جدول • ا: شاخص هاى برازش مدل براى متغير وابسته ميزان عمل جراحى زيبايى در شهر شيراز

\begin{tabular}{|c|c|c|c|}
\hline Cox \& Snell $\mathbf{R}^{2}$ & -2 Log likelihood & Chi Square $\left(\chi^{2}\right)$ & سطح معنادارى \\
\hline$\cdot \pi V r$ & $|V| / \cdot V V$ & $01 / \pi 90$ &. \\
\hline
\end{tabular}

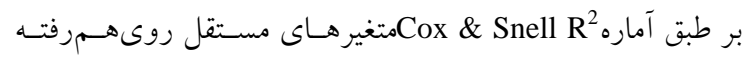

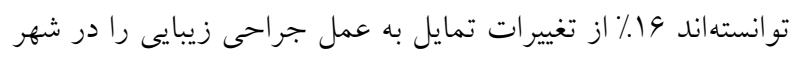
شيراز توضيح دهند. جدول با شامل ضرايب ركرسيون، آماره آزمون(والد) و سطعح

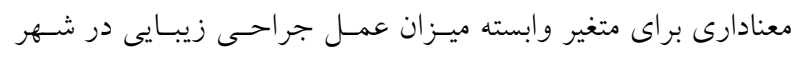

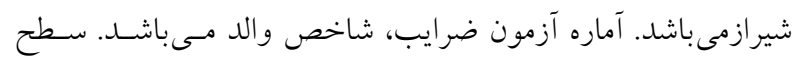

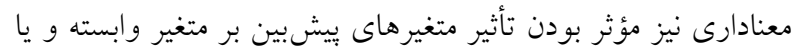

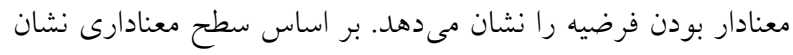
دادشده تمامى ضر ايب رگرسيون معنى دار مىباشند.
بر طبق آماره Cox \& Snell R متغيرهاى مستقل روىهـمرفتـه

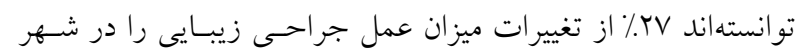

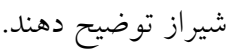
جدول لا شامل ضرايب رگرسيون، آماره آزمون(والد) و سطعح

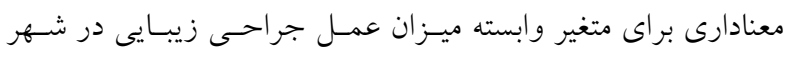

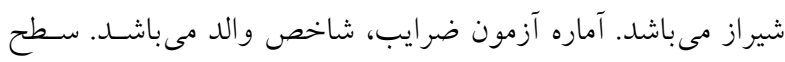

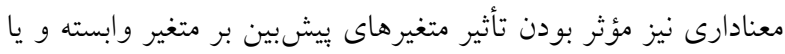

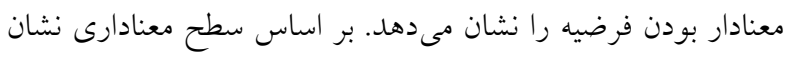
دادشده تمامى ضرايب رگر سيون معنى دار مى باشند.

\begin{tabular}{|c|c|c|c|c|}
\hline نتيجه فرضيه & مقدار معنادارى & آماره والد & ضريب بتا & متغيرهاى بيشبين \\
\hline تائيد مىشود & $\% \cdots$ & $r Y / .91$ & $-1 / \cdot \wedge r$ & تصوير بدنى \\
\hline تائيد مىشود & .1 .10 & r/৭91 & $-\cdot N T r$ & عزتنفس \\
\hline تائيد مىشود & $\% \cdots$ & TY/MTQ & 91.01 & مقدار ثابت \\
\hline
\end{tabular}

جدول rا: شاخصهاى برازش مدل براى متغير وابسته تمايل به عمل جراحى زيبايى در شهر شيراز

\begin{tabular}{|c|c|c|c|}
\hline Cox \& Snell $R^{2}$ & -2 Log likelihood & Chi Square $\left(\chi^{2}\right)$ & سطح معنادارى \\
\hline.$/ 10 \wedge$ & $r \wedge \Delta / 1 Q^{\prime}$ & $4 \cdot / r \wedge \Delta$ &.$/$ \\
\hline
\end{tabular}


جدول با ضر ايب ركر سيون، آماره آزمون و مقدار معنادارى براى متغير وابسته تمايل به عمل جراحى زيبايى در شهر شيراز

\begin{tabular}{|c|c|c|c|c|}
\hline نتيجه فرضيه & مقدار معنادارى & آماره والد & ضريب بتا & متغيرهاى ييشبين \\
\hline تائيد مىشود & $\cdot \cdots$ & $r \mu / \cdot \Delta \Lambda$ & $-1 / \cdot V r$ & تصوير بدنى \\
\hline تائيد مىشود & $\cdot / \cdot Y V$ & $1 /$ TKY & $-\cdot / 4 \cdot 1$ & عزتنفس \\
\hline تائيد مىشود & 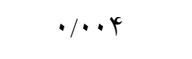 & $N / T \Delta G$ & $r / 911$ & مقدار ثابت \\
\hline
\end{tabular}

تعريف مى شود. به عبارتى زنـان همـواره در معـرض زل زدنهـاى

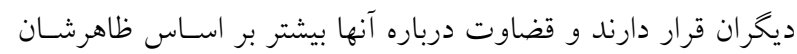

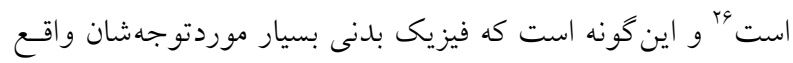

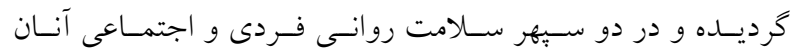
اثربخش مى باشد. در اين مطالعه، همانطور كه ذكر شد دو مؤلفه مهم روانشناختى تصوير بدنى و عزتنفس، مرتبط بـا جر احسىهـاى زيبـيـى در نظـر

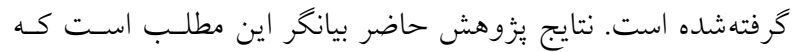

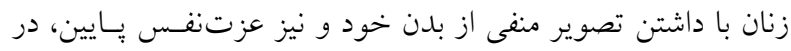

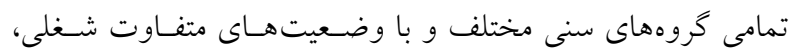
تحصيلى، درآمدى و هـر نـوع وضـعيت تاهـل، تمايـل و يــا اقـدام بيشترى به جراحى هاى زيبايى دارند كه علاوه بر صرف هزينـهــاى دراى بالا، خطر جانى نيز در بى خواهد داشت. به نظر مىرسد نظارت روانشناسان و جامعه شناسان بـر برونساندان

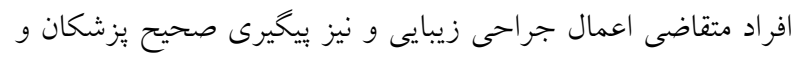
اجتناب از برآورده كردن خواستهـهـاى غيرمنطقى افـراد در اعمـال جراحى، مى تواند بهعنوان راهكارى در كاهش نرخ تقاضاى اينكونسه.

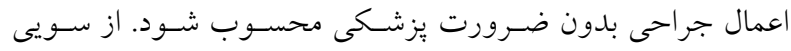

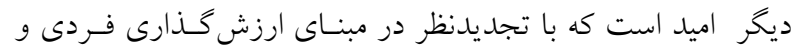
اجتماعى و همجنين بها دادن به معيارهـايى فراتـر از جسـم، شـاهد كاهش نرخ جراحىهاى زيبايى در ايران باشيم.

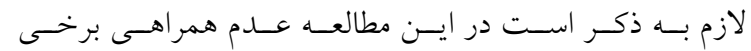

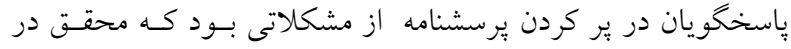

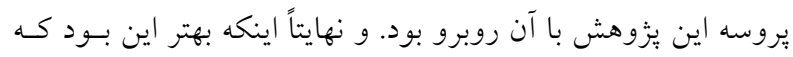

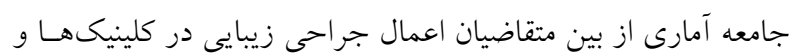

با توجه به نتايج بهدستآمده از ضريب ركرسيون، آماره والـــ و سطح معنادارى مى توان كفت كه تصوير بدنى و عزتنفس در سطح

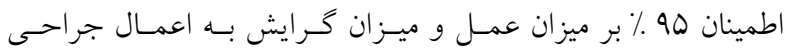

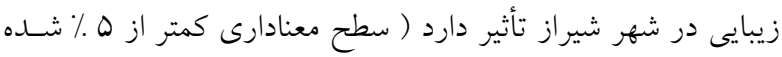

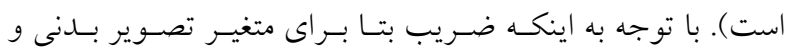

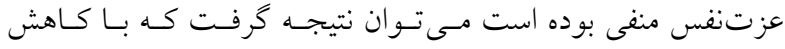
رضايت از تصوير بدنى و كاهش عزتنفس در سطح اطمينـان 90٪ احتمال ميزان عمل و ميزان كرايش به اعمال جراحى زيبـايى بـالاتر

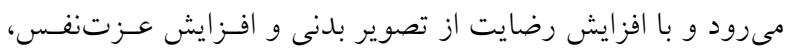

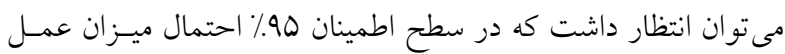

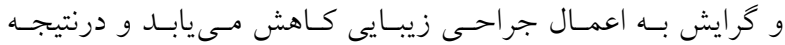
فرضيات تحقيق تائيد مى خردد.

\section{بحث و نتيجه گيرى}

همانطور كه ذكر شـــ در دوره جديـد، بــن زنـان بـه مبحثى اجتماعى بدل شده و بيش از آنكـه هويـت فــدى آنـان را آشـكار

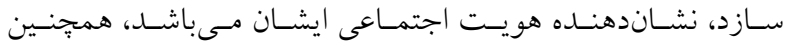

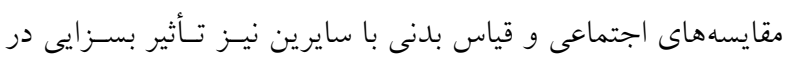

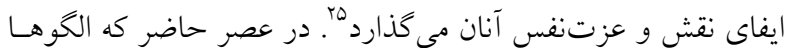
و معيارهاى زيبايى حاكم در جامعه، از طرق مختلف به فرد تحميـل و ارائه مى گردد و باعث ترغيب وى بـه سـمتوسـوى راهكارهـاى

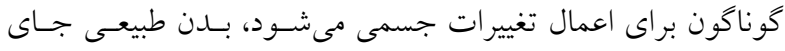

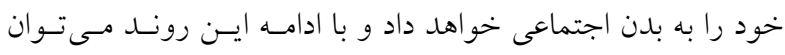

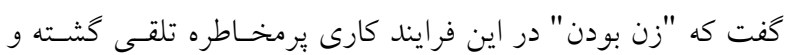

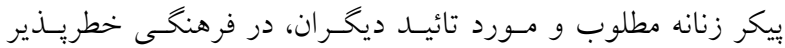




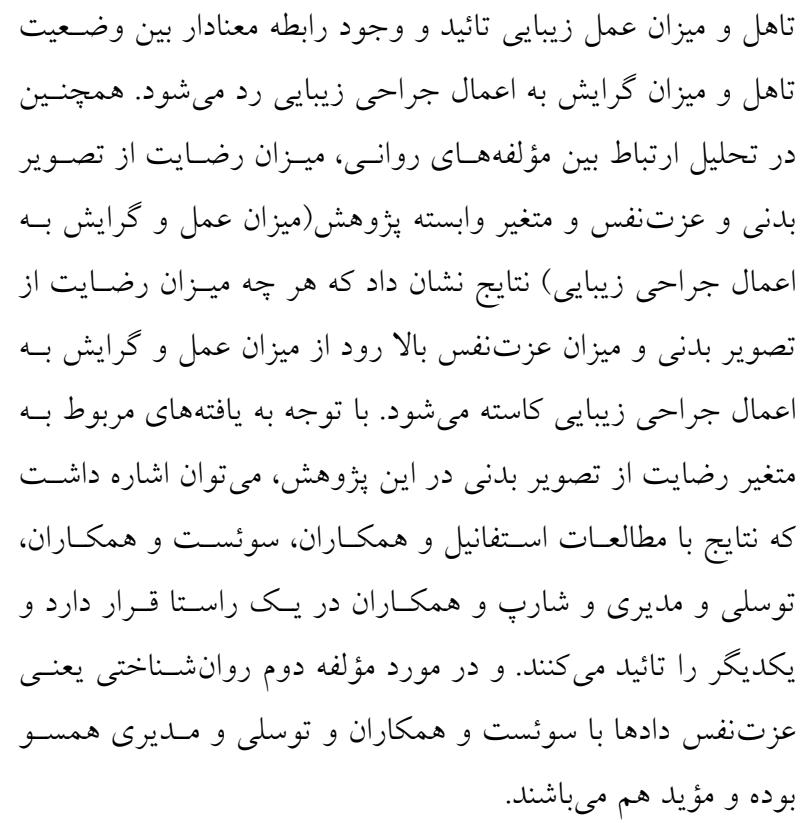

\section{References}

1. Entwistle J. Wilson E. Body dressing 2001.

2. Gimlin D. The other of aesthetic plastic surgery: body and society. 2010.

3. Giddens A. Modernity and self-identity. Translated by Movafeghian N. 2013 [In Persian].

4. Macgregor FC. Social psychological and cultural dimensions of cosmetic and reconstructive plastic surgery. Journal of Aesthet Plast Surg 1989; (13): 1-8.

5. RezaeeA. Inanloo M. Body management and its related to social variables among girls of Mazandaran university. Journal of women strategic studies 2010; (47)[In Persian].

6. Tvassoli Gh, Modiri F. The study of women's tendency to cosmetic surgery in Tehran. Journal of Sociological and psychological women's studies 2012;( 1): 61-80 [In Persian].

7. Giddens A, The consequences of modernity. Translated by Solasie M, Tehran. 1990 [In Persian].

8. Rahimimovafagh A.Aminesmaeeli M. Hefazi M. Rafiyee H. Shariat V.Sh V. National priority setting for mental health in Iran 2014; 3(20): 196-197[In Persian].

9. Heidarkhani H. Reshadi M. Rahmani Gh. The Study of the relationship between cultural capital and body management among women aged (15-29) in Kerman. Journal of women and culture 2012; (18): 55-69 [In Persian].

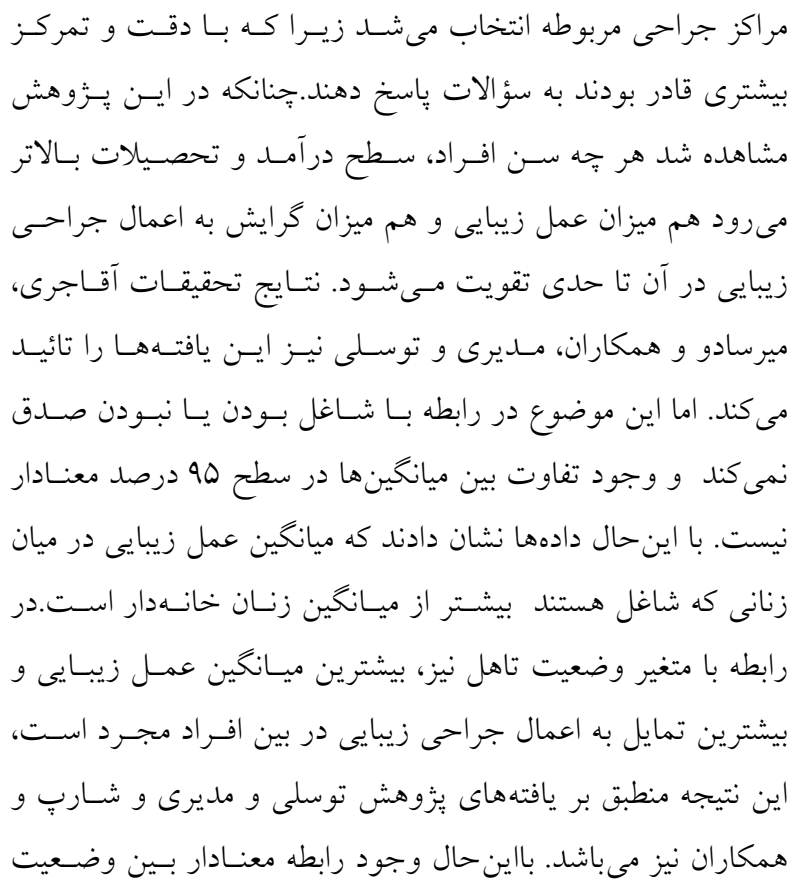

10. Shamshiri B. Freidooni Z. The self concept from the perspective of humanistic psychology by emphasizing on comparative method. Journal of psychological models and methods 2014;4 (16): 65-84[In Persian].

11. Ritzer G. Modern sociological theory. Translated by Solasi M. 1998 [In Persian].

12. Coser L. Masters of sociological thought. Translated by Solasi M. 2000 [In Persian].

13. Festinger L.A theory of social comparison process. London. Sage publication 1954;(6): 117-140

14. Suls J. Weeler L. Hand book of social comparison: Theory and research, C.R. Snyder 2013.

15. Shahbazi M. Sociological review on the phenomenon of brain drain and factors of that among faculty members in zanjan universities. (dissertation).Azad Zanjan university. 2007; 240 [In Persian].

16. Bigdeloo M. Mirzayee S. Confidence in Terms of Students and How to strengthen it Between Students. Journal of Psychology, 2016 ; (1) : 16-25[In Persian].

17. Mirsado T. kaldi AR. AataeiB.Therelationship between socio-cultural factors and women's tendency to cosmetic surgery in karaj. Journal of women and family studies 2010; 3(10): 145-164 [In Persian].

18. TvassoliGh, Modiri F.The study of women's tendency to cosmetic surgery in Tehran. Journal of Sociological and psychological women's studies 2012;(1): 61-80 [In Persian]. 
19. Aghjari S.A sociological study of makeup and Cosmetic surgery in Tehran.(Dissertation). Tehran University 2014;190 [In Persian].

20. Stefanile C. Nerini A. Matera C. The factor structure and psychometric properties of the Italian version of the acceptance of cosmetic surgery scale. Journal of body image 2014; 11: 370-379.

21. Soest T. Kvalem I. Skolleborg k. Roald H. Cosmetic surgery and the relationship between appearance satisfaction and extraversion: Testing a transactional model of personality. Journal of research in personality 2009;43:117-125.
22. Sharp G. Tiggman M. Mattiske J. The role of media and peer influences of Australian women's attitude towards cosmetic surgery. Journal body image2014;11: 482-487.

23. Rosenberg M. Society and the adolescent self-image 1965.

24. Schilder P. The image and appearance of human body 1950.

25. Macgregor FC. Social psychological and cultural dimensions of cosmetic and reconstructive plastic surgery. Journal of Aesthet Plast Surg1989; (13): 1-8.

26. Giddens A. Modernity and self-identity. Translated by Movafeghian N. 2013 [In Persian]. 